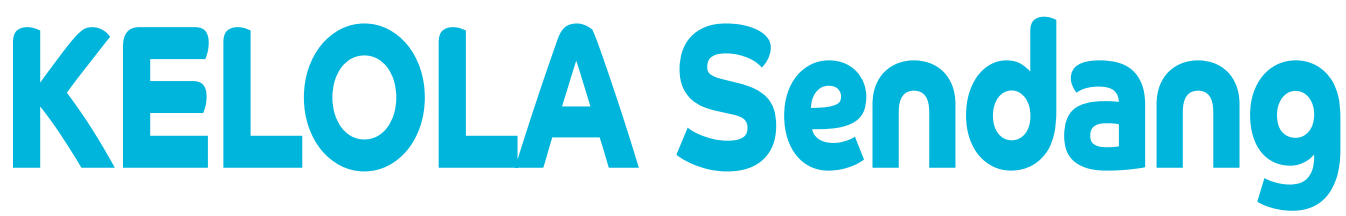

Kemitraan Pengelolaan Lanskap Sembilang Dangku

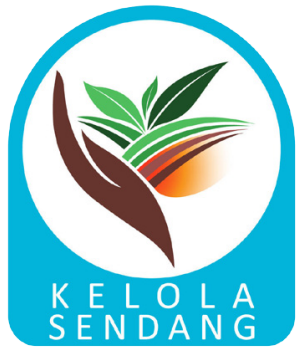

\title{
Exploring the Potential of Nipa Palm for Ecosystem Restoration and Climate Change Mitigation, Sustainable Rural Livelihoods and Renewable Energy
}
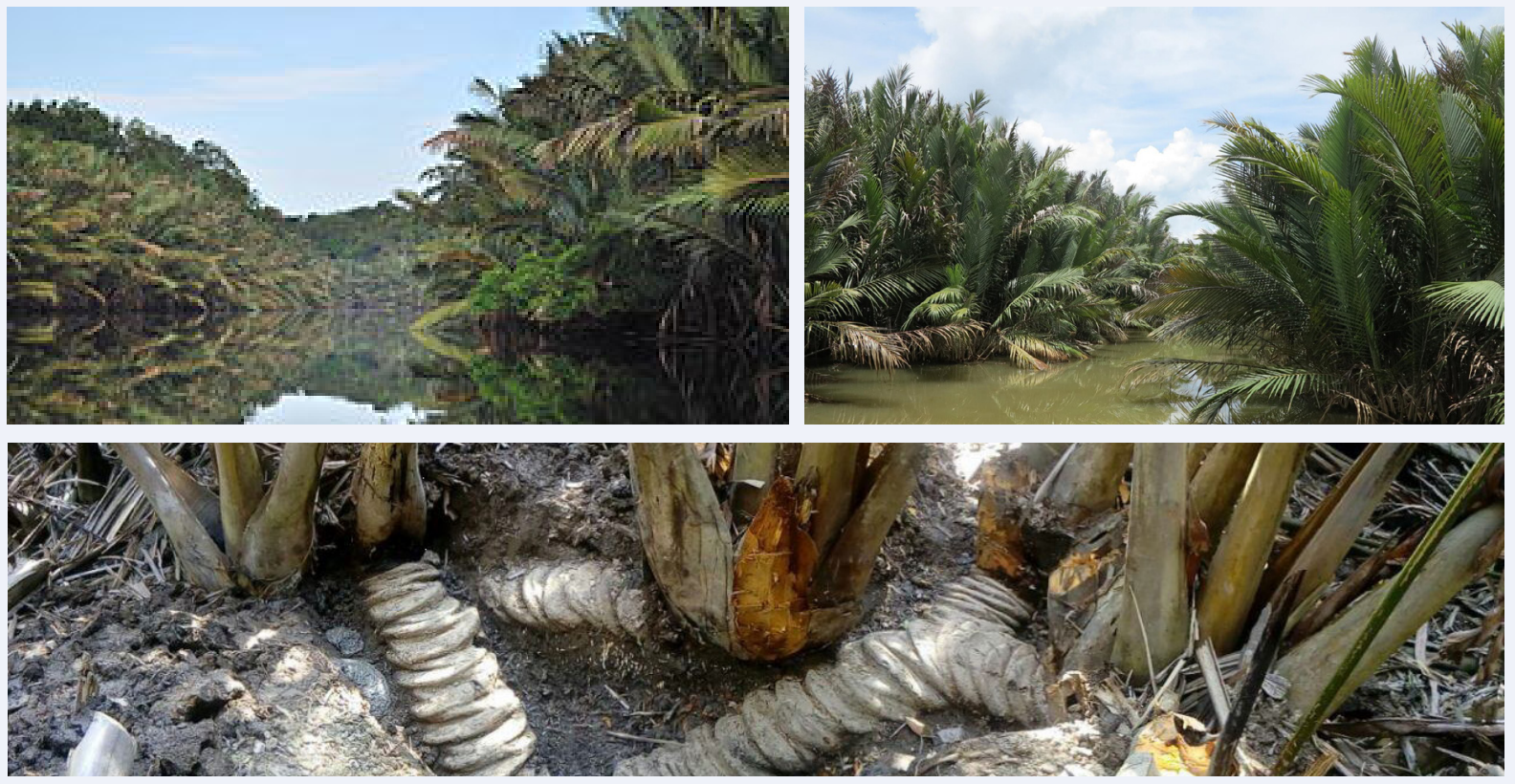

Nipa palm in Berbak Sembilang National Park (above left); Nipa growing in brackish water in estuary (above right); Exposed underground trunks of nipa palm (bottom). Photos: ZSL

\section{Introduction}

Nypa fruiticans, commonly known as Nipa Palm, is a species of palm native to the coastlines and estuarine habitats of the Indian and Pacific Oceans. In Indonesia, nipa palm covers about 700,000 ha, while, in South Sumatra, the Nipa Palm is a natural component of mangrove forests and covers extensive areas along the coast, estuaries, and riparian zones of rivers. About half of the natural nipa palm ecosystem in South Sumatra has been disturbed by human activities and requires restoration. Since Nipa Palm can be used to produce nipa palm sugar, natural nipa palm forests have the potential to generate sustainable rural livelihoods for those living in the lowland zone. More recently, nipa palm has been identified as a potential source of renewable energy. The sugar rich sap can be used to produce ethanol, a biofuel. Because of this potential, the KELOLA Sendang Project is exploring the potential of nipa palm for ecosystem restoration and climate change mitigation, sustainable rural livelihoods and renewable energy. 


\section{Botany and Ecology}

ypa fruticans is the only palm considered adapted to the mangrove biome, where it prefers brackish water conditions. The natural habitat of Nipa plan has an optimum salt concentration of 1 to 9 parts per million with soil types described as muddy and rich in alluvial silt, clay and humus and a pH of around 5. There is usually a high content of various inorganic salts, calcium, and sulphides of iron and manganese. Nipa palm can survive at an average minimum and maximum temperature of $20^{\circ} \mathrm{C}$ and $32-35^{\circ} \mathrm{C}$, respectively.

Nypa fruticans is best adapted to grow in mangrove coastal areas with only moderate salt loads, and grows best in calm estuaries and coastal zones. The species can dominate in a single channel or complex tributaries, bays, tidal flats and creeks, as long as there is a tide and a freshwater outflow action. Nipa palm usually thrives in the sediments deposited by an accreting process by the sea, creating a clayish type of soil, with brackish water that promotes an anaerobic system. Nipa palm can be found inland, as far as the tide can deposit the Palm's floating seeds. It can tolerate infrequent inundation, so long as the soil does not dry out for too long. Its horizontal underground creeping stem stabilizes river banks preventing soil erosion. New fronds emerge quickly after damage and so quickly protects the land after storms and also continuously produces useful products for local people.
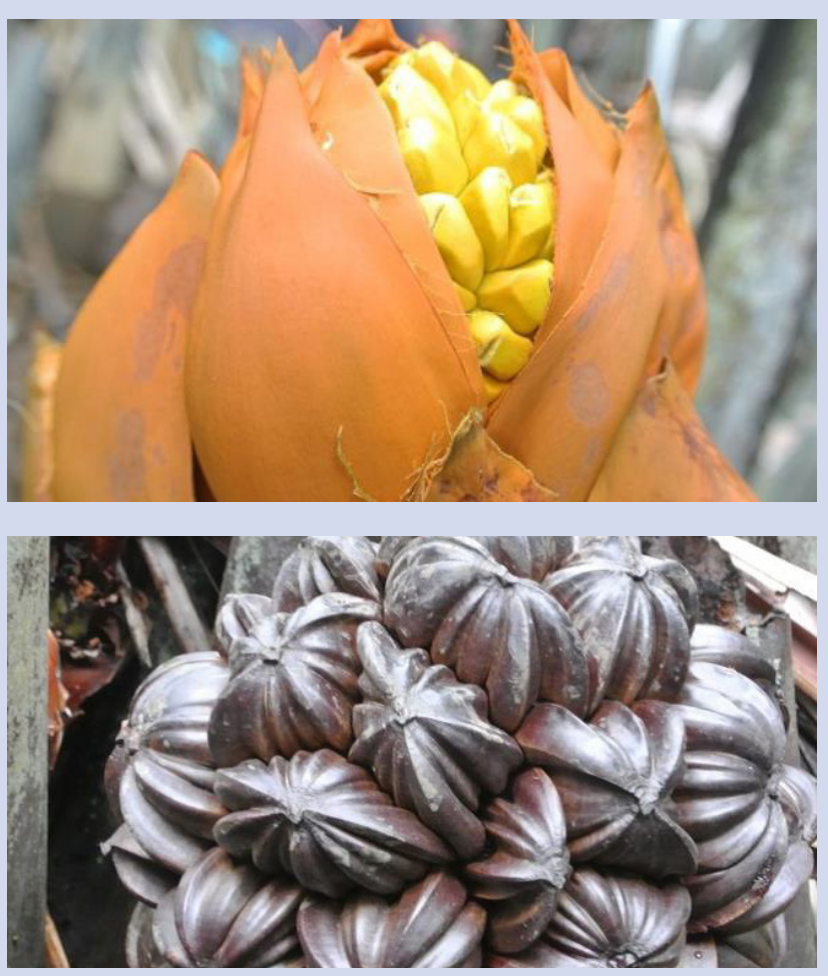

The nipa palm's trunk grows beneath the ground and only the leaves and flower stalk grow upwards above the surface. This unusual palm tree can reach $9 \mathrm{~m}$ (30 feet) in height. The younger leaves appear from the middle of the crown and push the older leaves aside before they dry and fall, leaving bulbous leaf bases or scars behind. The diameter of the cluster can be up to $75 \mathrm{~cm}$. The mature crown may contain 6 to 8 living leaves and 12 to 15 bulbous leaf bases at a time.

Nipa is a monoecious palm. The flowers are in a globular inflorescence with female flowers at the tip and catkinlike red or yellow male flowers on the lower branches. The flowers produce woody nuts arranged in a globular clusters up to $25 \mathrm{~cm}$ across on a single stalk. The ripe nuts separate from the ball and float away on the tide to be widely dispersed. Nipa palm can be found as far inland as the tide can deposit the floating nuts. The seeds exhibit viviparous germination (germinating while still attached to the tree), like many other mangrove species.

Once established from seed, nipa palm spreads by means of thick, prostrate-branching, subterranean rootstock. Thus, nipa palm forms extensive pure stands by virtual of its rhizomatous dichotomizing habit. Nipa palm favours brackish water, often forming a wide border beyond the fringe of adjacent mangroves or swamp forest. It does not occur on shores exposed to heavy wave action and never in hypersaline conditions.
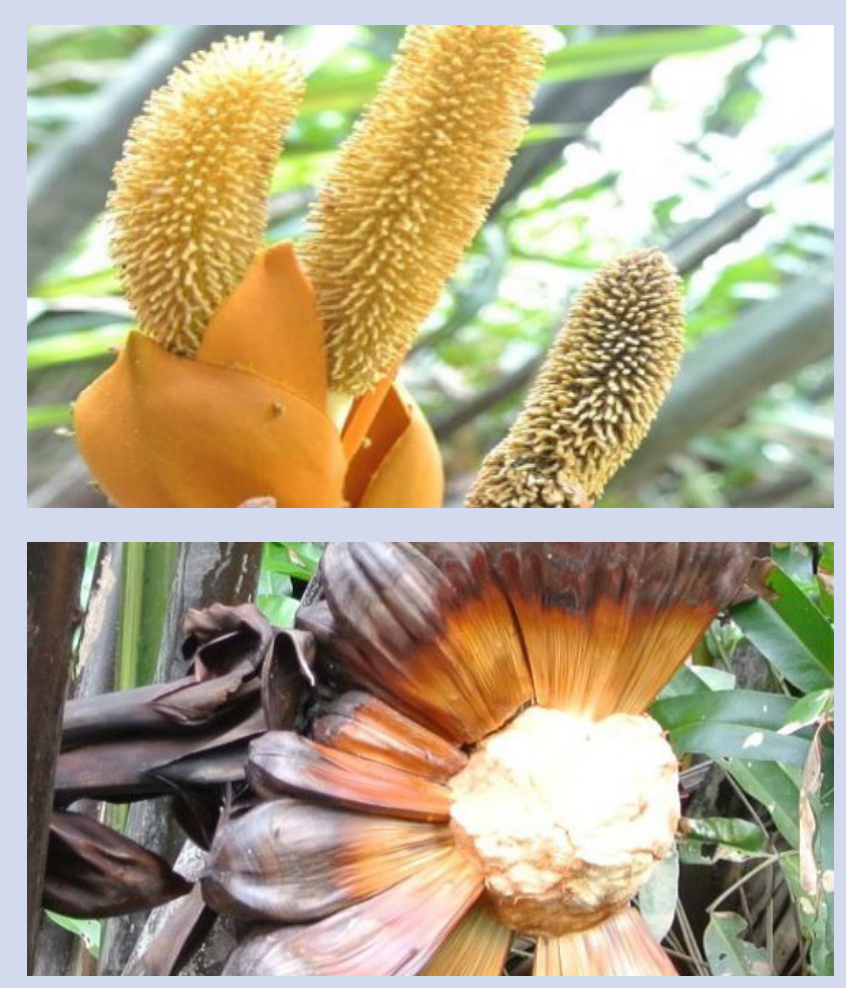

Female flower (above left); Male Flowers (above right); Mature fruit bunch (bottom left); Ripe nuts separating from cluster (bottom left). Photos: ZSL 


\section{Rehabilitation}

ecause of these characteristics, it is relatively easy to D rehabilitate disturbed brackish areas with nipah palm. If left, most disturbed areas will regenerate as a result of natural regeneration. Once established by seed, nipah palm will quickly increase to occupy the site through branching of subterranean rootstock and develops into extensive pure stands.

Nipah palm can also be planted and grown from seed, and this technique has been successfully used to reclaim paddy fields where the subsoil is under saline conditions. Nipah palm has also been successful planted in abandoned shrimp ponds to rehabilitate such brackish ecosystems.

Under field conditions, germinating nipa seeds can be planted in small holes and buried. Without burying, the nuts are easily attacked by rats or swept away by flood water. Planting time is normally in the dry season

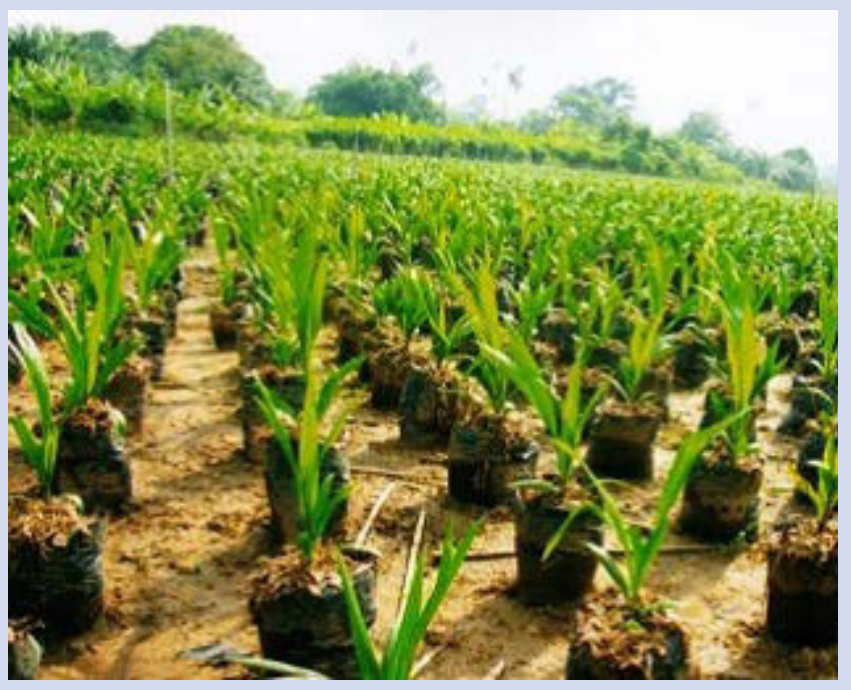

Nipa palm seedlings being prepared for planting (left); Nipah palm plantation established for production of bioethanolKedah, Malaysia (Pioneer Vaccination Biotech Corporation Sdn. Bhd.) (right). Photos: ZSL

\section{Traditional Uses}

ipa palm has been traditionally uses by humans for many purposes. Throughout its range, nipa palm leaves have been used for housing. The long, pinnate leaves (fronds) provide material for thatching houses. In the Philippines, Malaysia, Indonesia and Thailand the fabrication of thatching panels, called locally 'shingles', 'pawid' or 'attap', is a significant local source of income.

Leaflets and midribs are used for manufacturing of brooms, baskets, mats, sunhats, umbrellas, raincoats, ropes, and cigarette wrappers. Local fishermen use the leaves for sails, and the rootstock to float their nets. where there is adequate soil moisture and depth. Normally, a spacing of $2 \times 2 \mathrm{~m}$ is recommended. One year after planting, seedlings reach $50 \mathrm{~cm}$ in height, and by year three seedlings reach $2 \mathrm{~m}$ in height. Due to the dichotomous branching of the underground stem, a thick clump is formed when the Nipa plant is 5-6 years of age.

In Malaysia, nipa palm plantations have been established using seedlings prepared in polybags using selected seed from superior sap producers. The company expects this to lead to improved sap production for processing into sugar and other food production, or for the production of ethanol as a biofuel.

Rehabilitated nipa palm forests sequester large quantities of carbon, and also serve as a sink with carbon store both above and below ground. It is estimated by nipa palm forests contain 4 times as much carbon as lowland forests. They also provide good breeding grounds for a range of fish, crustaceans, and molluscs.

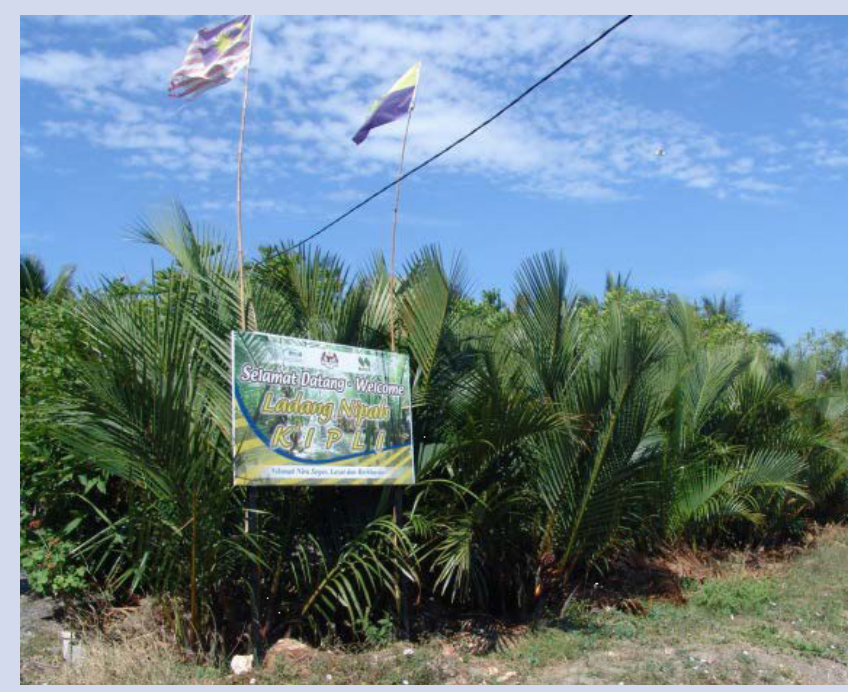

In the past, salt was extracted from nipa palms. Dried leaves, petiole, stem wood, and fruit residues are used as fuel.

Nipa palm has also been traditionally used for medicines. For example, ash of burned nipa palm material is used to treat toothaches and headaches. Newly developed shoots are used as a vermicide.

The hardened endosperm ripened fruits are used as vegetable ivory and buttons. In Nigeria, the hard shell (mesocarp) is used in the making of buttons, necklaces and other fashion apparels. 


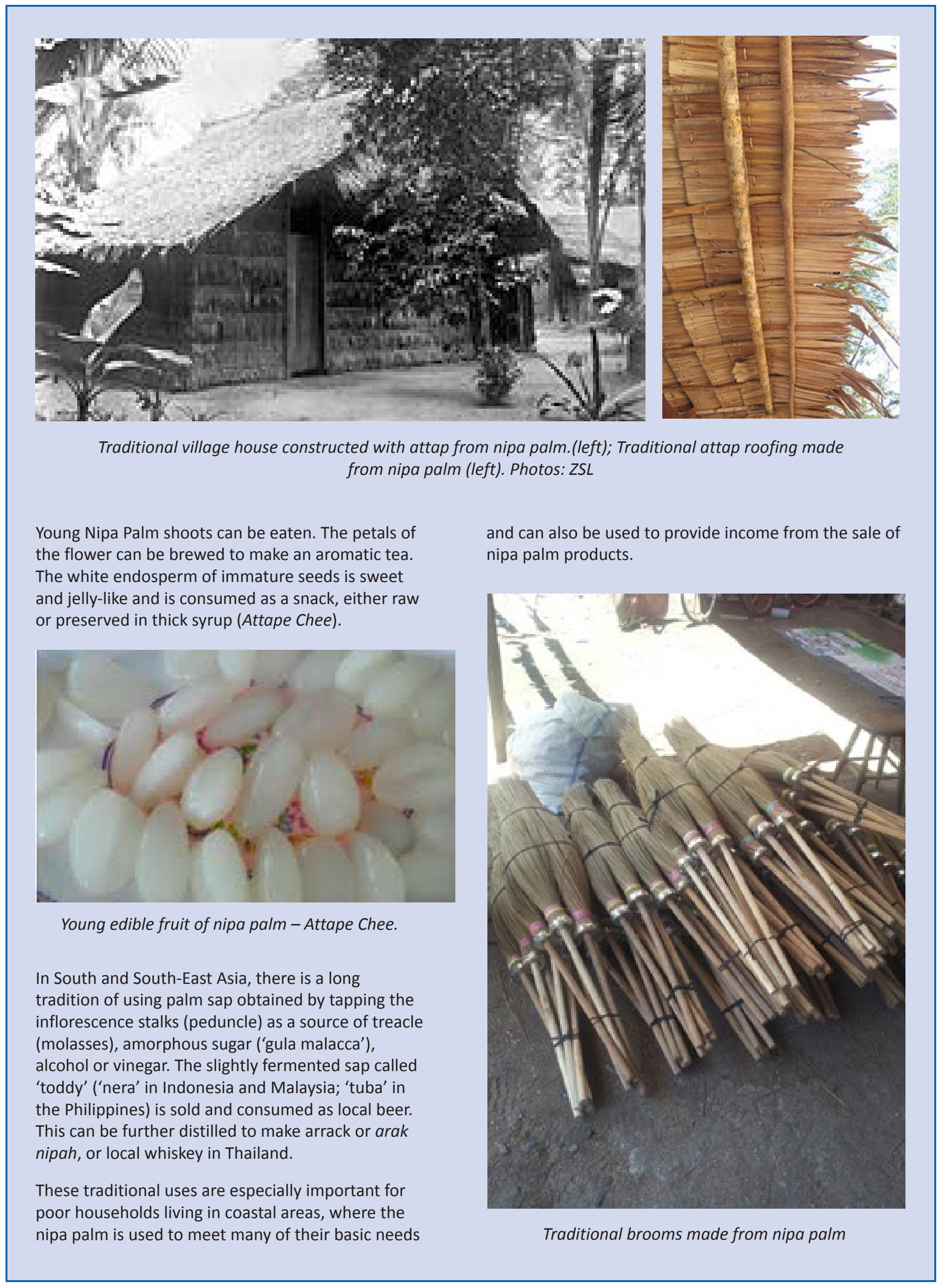




\section{Modernizing the Production of Traditional Products for Sustainable Livelihoods}

\section{Nipa Palm Sugar and Other Food Production}

I recent years, there has been a renewed interest in producing palm sugar and other food products from nipa palm. This has led to a modernizing of methods for production, processing and marketing. The renewed interest is related to the perceived health benefits of nipa palm sugar, which is classified as an alternative sugar and is considered a healthy organic substitute for synthetic sugar which is ideal for diabetics, overweight people, and 'the health-conscious'. Nipa palm sugar can be used as a sweetener and ingredient in foods and confectionery products like pastries and local delicacies. Simple technical improvements have resulted in improved products.

Innovations have been made to the collection system. For example, flexible pouches or sterile plastic is often used to collect the sap. This method minimizes the exposure of the sap to air and contaminants and allows for the hygienic collection of sap in line with food security requirements.

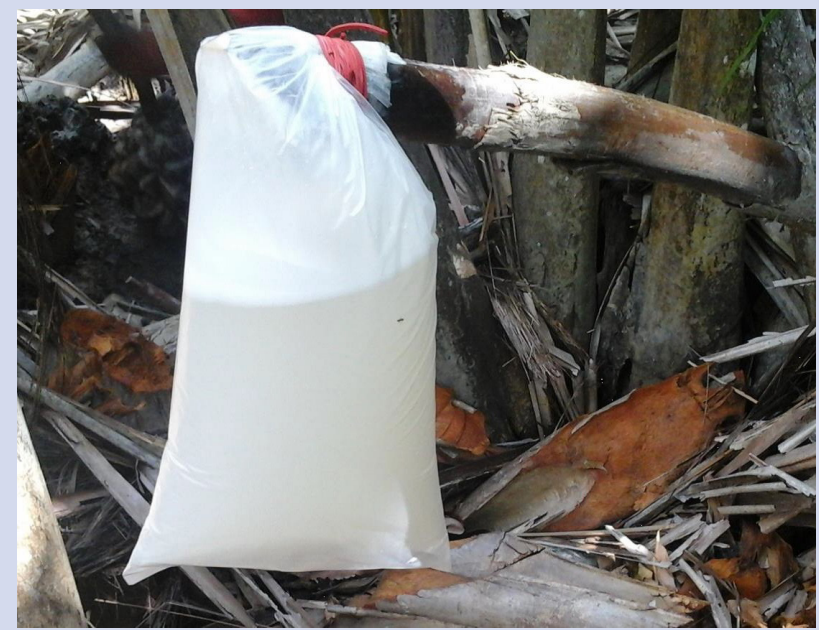

Nipa sap being collected in hygienic plastic container. Photo: ZSL's Documentation

There have also been improvements in the processing equipment used in cooling the nipa sap to produce sugar. The collected nipa sap is boiled or cooked using a modified fire-tube-steam jacketed kettle, replacing the direct heating in open pans traditionally used by processors. With this innovation, scorching during cooking is avoided.

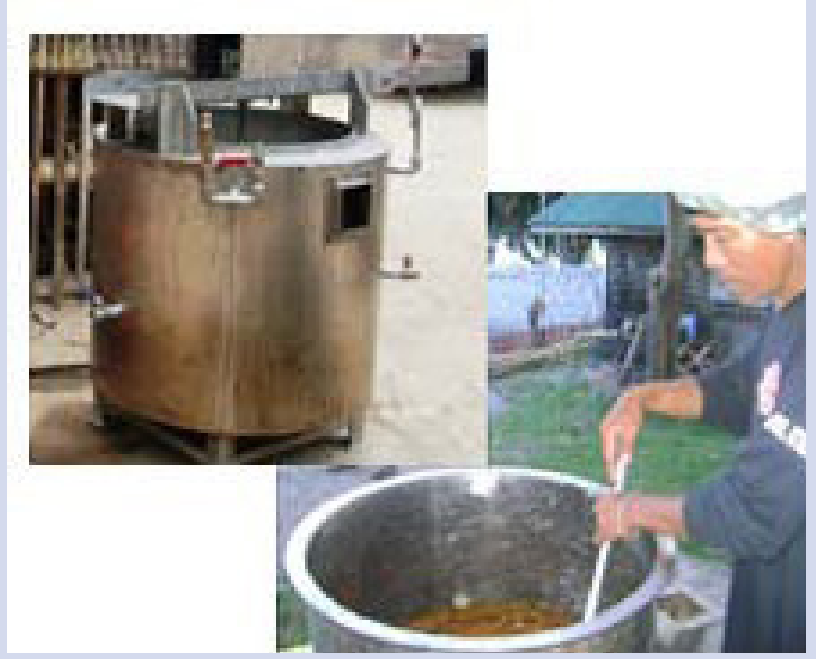

Modified fire-tube-steam-jacket kettle

Income from collecting and processing nipa palm sap can exceed the income from other rural livelihoods. For example, in Pak Phanang Basin, Southern Thailand, income from collecting and processing nipah sap into sugar exceeds other livelihood options. There are 4850 farmers (60-70\% of population) harvesting nipa sap sustainably from 3,200 ha. The nipa palm stands have been harvested sustainably for over 200 years without a decline in production.

Potential sugar production from nipa palm forests in South Sumatra are similar to those from these producer areas.
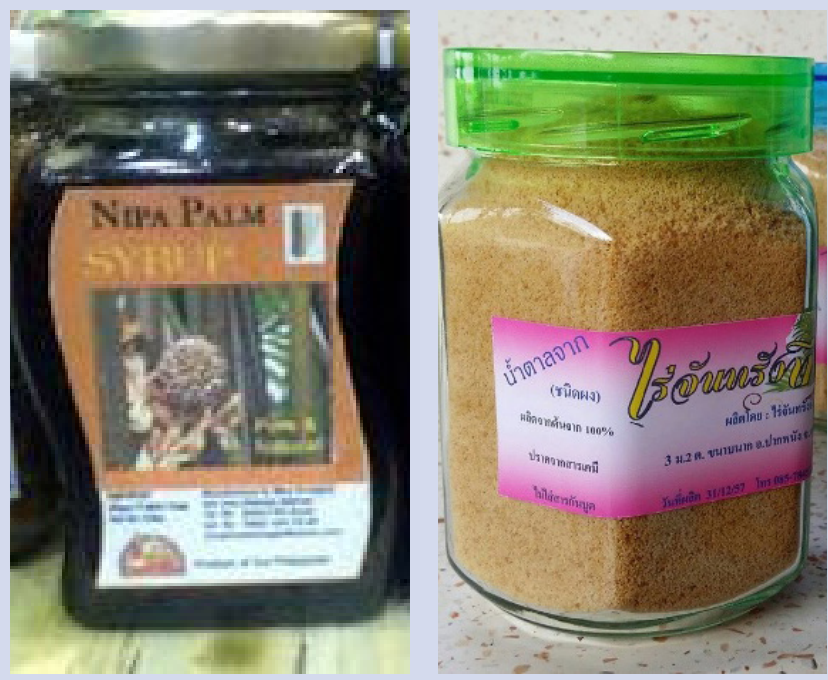

Syrup from nipa palm (left); Palm sugar produced from nipa palm (right) 


\section{Renewed Interest in Nipa by Tourism Industry}

Tourism is one of the largest and fastest growing parts of the economy in south-east Asian countries. There is a recognized demand for traditional or rustic accommodation, and also for restaurants and beach cottages made from traditional materials. As a result, there is a growing demand for roofing and panelling materials (attap) made from nipa leaves. Nipa is a fast growing and renewable resource, and the natural environment is benefiting from the sustainable

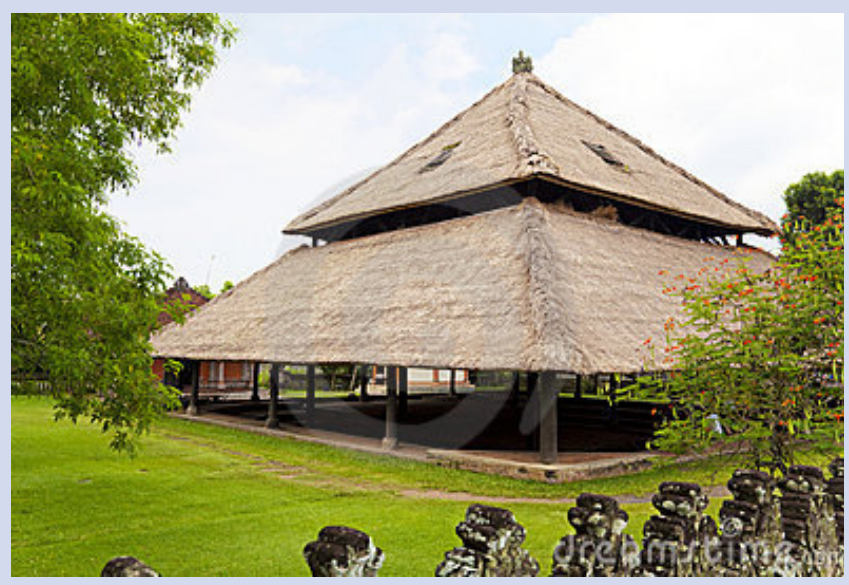

management of nipa to provide on-going supplies of attap for the growing tourism industry. This also provides employment both in the production of attap and in providing facilities for tourists, both domestic and international.

Eco-tourism is being promoted to add value to protected areas, and to build awareness of the important environmental services which these protected areas provide. Learning about the environmental and traditional economic importance of plants, such as nipa palm, builds local and international support for conservation.

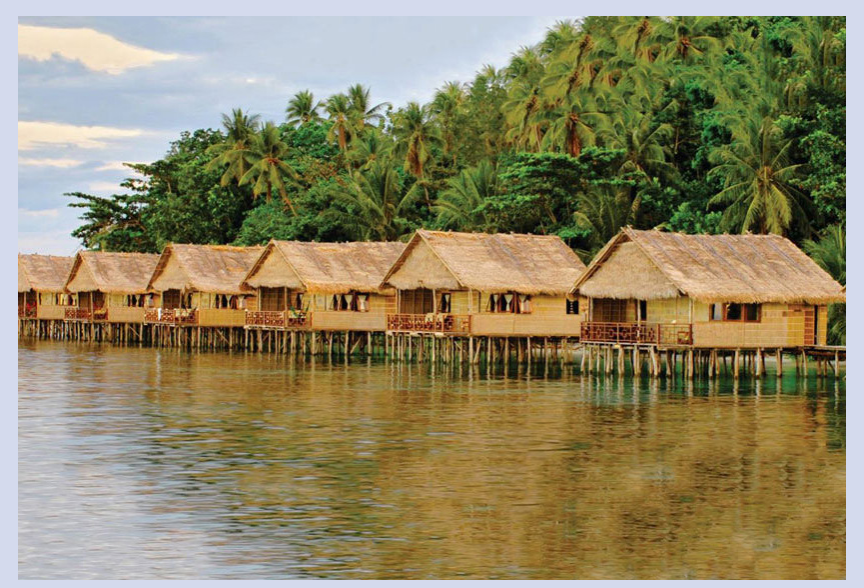

Building constructed in Bali with attap roofing from nipa palm (left).

Resort in Papua which has cottages built using nipa palm attap (right).

\section{Exploring the Potential of Biofuel from Nipa Palm}

For biofuel production, the single most important factor for success is the yield of the energy crop chosen. It is crucial for it to be as high as possible. Sugarcane, oil palm and cassava have given good results. There is however one underutilized species of tropical palm (Nypa fruticans), which holds a lot of promise when it comes to ethanol production in the tropics. Its habitat is river banks in the tidal zone and brackish wetlands, where the trunk is under ground and the leaves emerge up to $9 \mathrm{~m}$ tall in height. These large leaves absorb large volumes of photovoltaic and photosynthesis Carbon Dioxide $\left(\mathrm{CO}_{2}\right)$ during the day, and traps this Carbon Dioxide $\left(\mathrm{CO}_{2}\right)$ in the sugar-rich sap.

Recent studies have shown that nipa palm has significant potential for the production of biofuel in the form of bioethanol. This potential is illustrated in
Figure below from CIFOR. As shown, nipa palm has the potential to produce twice the amount of ethanol per ha as sugar cane, and four times that of corn. In doing so, it also provides a wider range of other benefits: (i) it is economical, (ii) it is a perennial with low input requirements (little or no chemical inputs into the environment), (iii) it provides protection from tidal surges, typhoons and tsunami, (iv) it enhances biodiversity (both terrestrial and aquatic), (v) it is smallholder friendly, (vi) sap can be collected without harvesting other biomass, and (vii) can be part of food co-production systems (producing both palm sugar and bioethanol). There are also studies that suggest that nipa palm serves as a natural filter removing heavy metal ions from aqueous solutions, and locking them within the plants. 


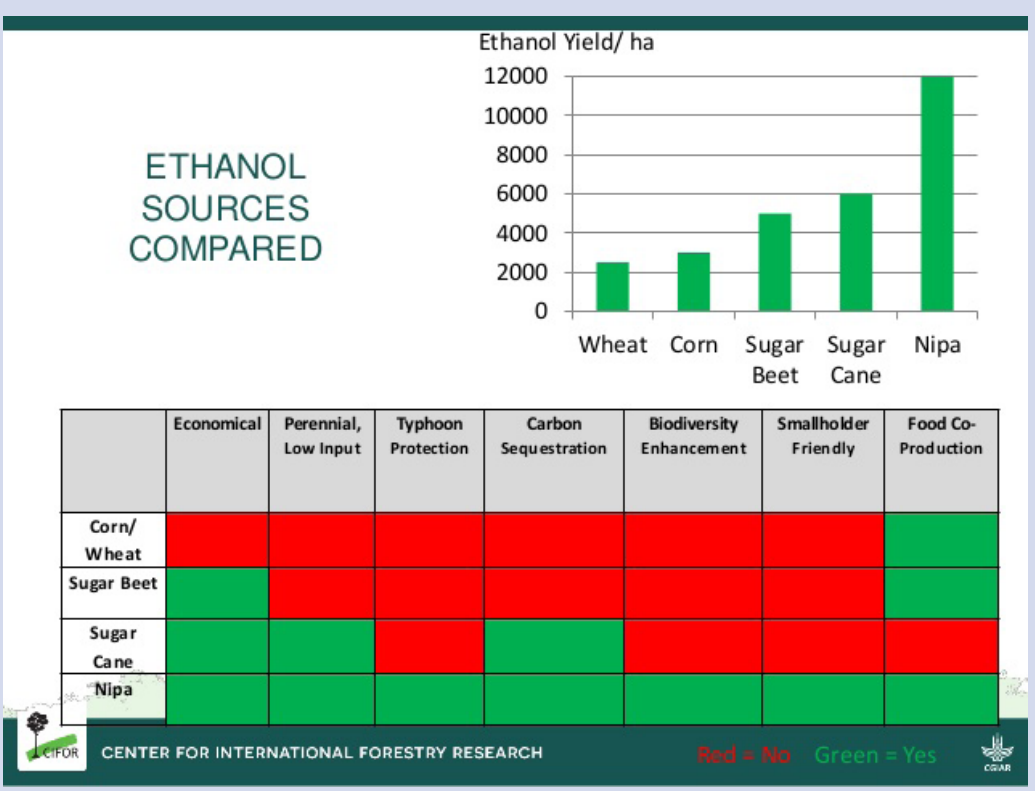

The Ethanol Production Flowchart below clearly illustrates the advantage that nipa sap processing has over other feedstocks. The process is shorter and requires less labour and energy inputs. Although not illustrated, nipa sap processing is also much more efficient than that required for the production of bioethanol from oil palm.

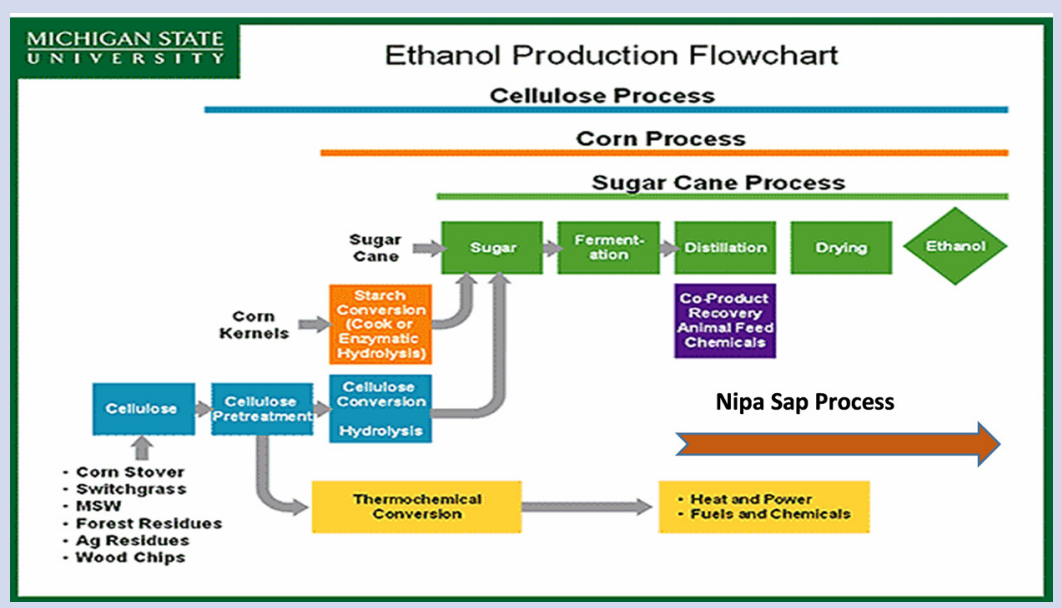

The sugar-rich sap from nipa palm is one of the very few natural biofuel sources that is non-toxic and that produces bioethanol. It takes about 13 litres of sugar-rich nipa palm sap to produce around 1 litre of bioethanol. The remaining 12 litres of residuals generate the by-product known as Captured Liquid Carbon Dioxide $\left(\mathrm{CO}_{2}\right)(\mathrm{CLCD})$ that can be used as BioOrganic Fertilizer. Good producing nipa palm can produce between 12,000-20,000 litres of ethanol per hectare per year, whereas corn and sugar cane can produce only 6,000-7,000 litres. Nipa palm sap can be collected daily from the trees without damaging the tree, thereby, providing permanent employment for workers. This is illustrated in south Thailand were nipa sap has been harvested for over 200 years from the same sites without declining rates of production or damage to the stands themselves. In damaged ecosystems requiring restoration, nipa can be easily planted from seed or seedlings. Nipah palm can be tapped 4 years after planting, and keeps yielding for more than 50 years, regenerating from underground stems and rootstock. Tapping nipa is labour-intensive and this promises the creation of many rural jobs. It is anticipated that skilled tappers can obtain enough ethanol feedstock to support commercial biofuel production and the production of CLCD bio-fertilizers, while gaining decent incomes that surpass official local minimum wages. The use of CLCD bio-fertilizers by agricultural producers and companies in the landscape could reduce the amount of chemical fertilizers going into the environment.

In the Philippines, nipa palm sap is being processed in mills set up to produce bioethanol from sugarcane. This fills the under-utilized capacity of the mills and reduces the average cost from bioethanol production with nipa being processed at a lower cost than sugarcane.

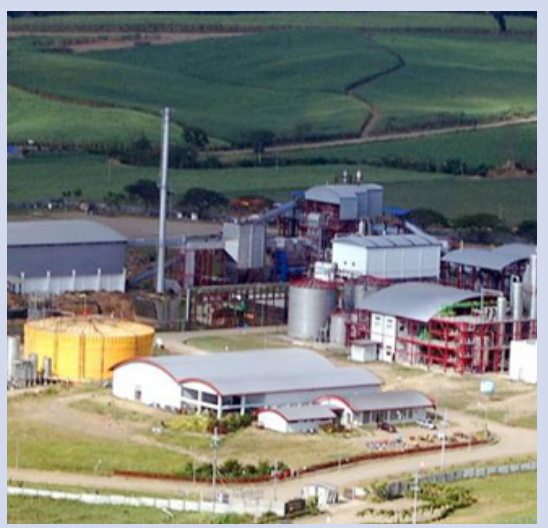

Mill for producing bioethanol from sugarcane, which is also processing sap from nipa palm.

There are also smaller distillation mills which can be used by cooperatives to produce bioethanol for local use, such as generators and motors adapted for the use of bioethanol. This is important for more isolated villages which are not connected to the government electricity grid, and find the purchase of gas and diesel expensive. 


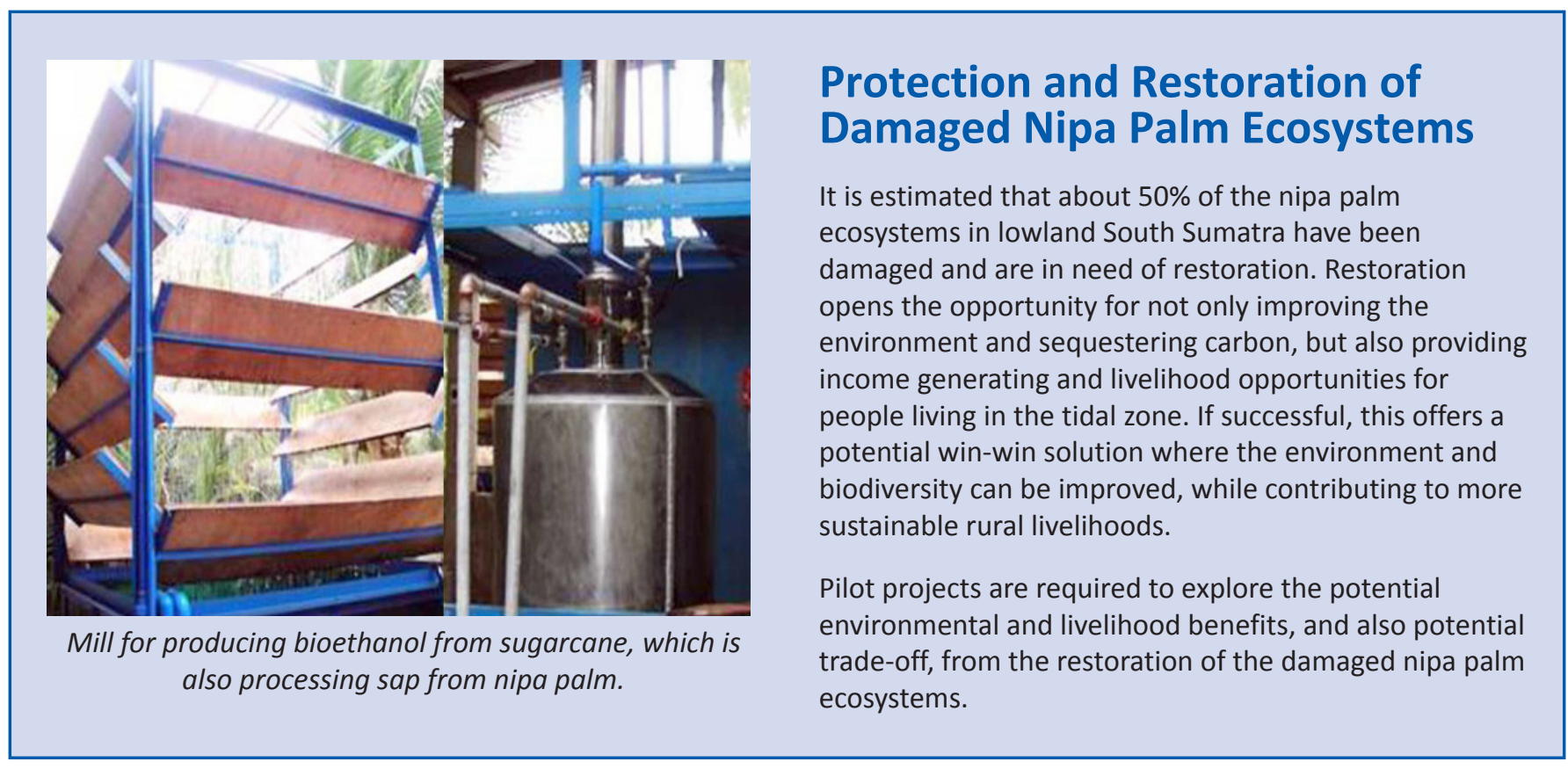

\section{References}

Bamroongrugsa, N., Buachum, S., Purintavarakul, C. (2008). Nipa Palm (Nypa fruticans Wurmb.) cultivation in salt affected paddy fields. J. Trop. Plants Res. 1: 93-102.

Bamroongrugsa, N. and Purintavarakul, C. (2008). Growing nipa palm for restoration of abandoned shrimp ponds. Wetl. Sci. 4(2): 91-95.

Biofuel Academy (2017). Fermentation of Nypa Palm to Form Ethanol. http://biofuelacademy.org/web-modules/process/ fermentation/fermentation-of-nypa-palm-to-form-ethanol/

Giesen, W., Wulffraat, S., Zieren, M. and Scholten, L. (2006). Mangrove Guidebook for Southeast Asia. Part VIII: Palms, Cycads and Pandans. FAO and Wetlands International, Bangkok.

Hamilton, L.S. and Murphy, D.H. (1988). Use and management of nipa palm (Nypa fruiticans, Arecaceae): a review. Econ. Bot. 42 (2): 206-213.

Hidayat, I.W. (2015). Natural production potency of nipa (Nypa fruticans) sap as production commodity for bioethanol. Pros. Sem. Nas. Masy. Biodiv. Indo., Volume 1, Nomer 1, Maret 2015, p.109-113.

Jian, S., Ban, J. and Yan, H. (2010). Low genetic variation detected within the widespread mangrove species Nypa fruticans (Palmae) from Southeast Asia. Aquat. Bot. 92: 23-27.

Marris, E. (2006). Sugar cane and ethanol. Drink the best and drive the rest. Nature, 444: 670-672.

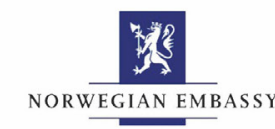

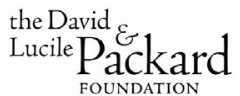

Matsui, N., Bamroongrugsa, N., Mormume, H. and Okimori, Y. (2011). Nipa Palm: A potential alternative source for bioethanol. Research Paper 14th Mangrove National Seminar. Thailand.

Matsui, N., Okimori, Y., Takahashi, F., Matsumura, K. and Bamroongrugsa, N. (2014). Nipa (Nypa fruticans Wurmb.) Sap Collection in Southern Thailand: I. Sap Production and Farm Management. Environ. Nat. Res. 4 (4): 75-88.

Ridho, R.M., Sundoko, A. and Ulqodry, T.Z. (2006). Analisis perubahan luasan mangrove di Muara Sungai Banyuasin, Sungsang dan Upang Provinsi Sumatera Selatan Menggunakan Citra Satelit Landsat-TM. Jurnal Pengelolaan Lingkungan dan SDA 4(2): 11-18. [Indonesian]

Tamunaidu, P., Matsui, N., Okimori, Y. and Saka, S. (2013). Nipa (Nypa fruiticans) sap as a potential feedstock for ethanol production. Biom. Bioe. 52: 96-102.

Tamunaidu, P. and Saka, S. (2011) Chemical characteristics of various parts of nipa palm (Nypa fruticans). Ind. Crop Prod. 34 1423-1428.

Tamunaidu, P. and Saka, S. (2013). Comparative study of nutrient supplements and natural inorganic components in ethanolic fermentation of npa sap. J. Jpn. Inst. Energy 92(2): 181-186.

Tsuji, K., Ghazalli, M.N.F., Nordin, Z., Khaidizar, M.I., Dulloo, M.E. and Sebastian, L.S. (2011). Biological and Ethnobotanical Characteristics of Nipa Palm (Nypa fruticans Wurmb.): A review: Sains Malays. 40 (12): 1407-1412.

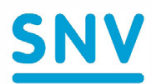

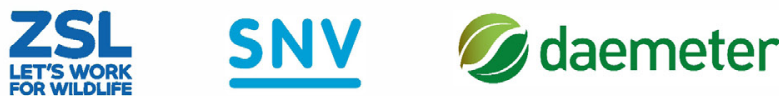
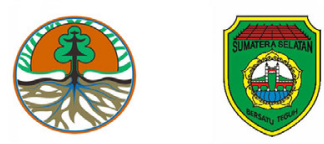

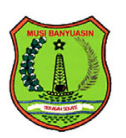

